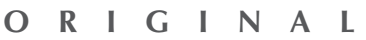

A $\quad R \quad T \quad$ I C L E

\title{
Tuberculin sensitivity testing and treatment of latent tuberculosis remains effective for tuberculosis control in human immunodeficiency virus-infected patients in Hong Kong
}

Ada WC Lin 連慰慈 Kenny CW Chan 陳志偉 WK Chan 陳惠結 KH Wong 黃加慶

Key words Antiretroviral therapy, highly active; HIV; Latent tuberculosis; Tuberculin test Tuberculosis

Hong Kong Med J 2013;19:386-92 DOI: $10.12809 / \mathrm{hkmj} 133892$

Integrated Treatment Centre, Special Preventive Programme, Centre for Health Protection, Department of Health, Hong Kong

AWC Lin, MB, BS, FHKAM (Medicine) KCW Chan, MB, BS, FHKAM (Medicine) WK Chan, BNurs, MNurs

KH Wong, MB, BS, FHKAM (Medicine)

Correspondence to: Dr AWC Lin Email: adalinwc@dh.gov.hk
Objective To evaluate whether a policy to treat latent tuberculosis identified by annual tuberculin sensitivity testing is effective for tuberculosis control in human immunodeficiency virus-infected patients in Hong Kong.

Design Historical cohort study.

Setting Integrated Treatment Centre, Department of Health, Hong Kong.

Patients Patients infected with human immunodeficiency virus without a history of tuberculosis were offered annual tuberculin sensitivity testing, coupled with treatment of latent tuberculosis if they tested positive. All such patients were followed for new tuberculosis.

Results In all, 1154 patients on antiretroviral therapy, contributing to 5587 patient-years of observation, were analysed; 1032 patients $(89 \%)$ received annual tuberculin sensitivity testing. Their baseline characteristics, including CD4 counts and other risk factors for tuberculosis, did not differ significantly from those who declined testing. The overall incidence rate of tuberculosis was 0.59 case per 100 patient-years. It was lower in those who received annual tuberculin sensitivity testing than those who did not $(0.41$ vs 3.85 per 100 patient-years; $\mathrm{P}<0.0001)$. Only a low baseline CD4 count and a history of tuberculin sensitivity testing were shown to be significant indicators of incident tuberculosis using multivariate analysis. The hazard ratio was 0.36 (95\% confidence interval, $0.16-0.85 ; \mathrm{P}=0.02$ ) for those with a baseline CD4 count of $100 / \mathrm{mm}^{3}$ or above, and 0.26 (95\% confidence interval, $0.08-0.77 ; \mathrm{P}=0.016$ ) for those who received annual tuberculin sensitivity testing. The incidence of tuberculosis was highest within 90 days of antiretroviral therapy initiation.

Conclusion The established policy continues to be effective. The high risk of tuberculosis during the early period of antiretroviral therapy supports early use of tuberculin sensitivity testing. Alternatively, the strategy of universal isoniazid preventive therapy at antiretroviral therapy initiation could be studied for those with very low baseline CD4 counts.
New knowledge added by this study

- In a setting with universal access to combination antiretroviral therapy (ART) and Bacillus Calmette-Guérin vaccination as in Hong Kong, the use of tuberculin sensitivity testing (TST) to identify latent tuberculosis (TB) for treatment continues to be effective for TB control in the human immunodeficiency virus (HIV)-infected population.

- Despite combination ART, HIV-infected patients with advanced disease are at high risk of TB especially in the early phase of ART initiation.

\section{Implications for clinical practice or policy}

- Identification of latent TB cases and treatment should be incorporated into local HIV care. Apart from TST, alternative methods should be explored to identify latent TB infection for treatment.

- Reducing the incidence of TB in HIV-positive patients at highest risk (ie with very low baseline CD4 counts) in the early phase of combination ART initiation warrants more research. 


\section{Introduction}

Tuberculosis (TB) is a major cause of illness and death in persons infected with human immunodeficiency virus (HIV). The geographical intersection of TB and the HIV epidemic has been devastating. ${ }^{1}$ An estimated 1.4 million incident cases of HIVassociated TB occurred in 2008 worldwide, which accounted for $25 \%$ ( 0.5 million) of all global deaths from HIV infection. ${ }^{2}$ In resource-constrained settings with a high burden of TB, treatment of latent TB infection in HIV-infected patients is highly effective in preventing TB. ${ }^{3}$ However, the use of antiretroviral therapy (ART) per se also reduces the incidence of $\mathrm{TB}^{4,5}$ It is therefore unclear whether treatment of latent TB infection as identified by annual tuberculin sensitivity testing (TST) will continue to be effective in a setting with universal access to ART and an intermediate burden of TB.

The burden of TB is intermediate in Hong Kong, where the overall prevalence of HIV is relatively low. ${ }^{6}$ With effective implementation of prevention and control measures (particularly case-finding and treatment), the incidence of TB has decreased significantly over the past five decades. ${ }^{7}$ In Hong Kong, the first HIV case was reported in 1984. As of the first quarter of 2012, the cumulative number of reported individuals with HIV infections was 5392. ${ }^{8}$ In Hong Kong, combination ART has been readily available since 1997, and is currently being prescribed in line with treatment guidelines for developed countries. ${ }^{9}$ The burden of TB in HIV-infected patients, however, remains a challenge in the territory. Over the past two decades, TB has remained the most important acquired immunodeficiency syndrome-defining condition in the local HIV-infected population. ${ }^{6,10}$ Moreover, TB endemicity in this locality renders HIV-infected patients prone to the infection early in the course of their HIV disease. To look into the effectiveness of a policy of annual TST and treatment of latent TB in HIV-infected patients in Hong Kong, we analysed data from a cohort of patients in a local HIV centre.

\section{Methods}

\section{Study design, subjects, and definitions}

The study population was drawn from the largest HIV clinic in Hong Kong, namely the Integrated Treatment Centre (ITC), Department of Health. The ITC provides specialist HIV care to patients, including ART, regular monitoring of CD4 counts, and HIV-1 RNA viral load determination every 3 to 6 months, drug adherence counselling, and psychosocial support. All patients underwent baseline chest radiography at the first clinic visit. In the ITC, TST was first introduced in July 1989. Subsequently, TST with 2 units of purified protein derivative RT23 were used at baseline and
結核菌素敏感性測試和潛伏性結核治療對 香港人類免疫缺陷病毒感染者的結核病控制 仍然有效

目的評估利用結核菌素敏感性測試檢測潛伏性結核及其治 療的政策, 作為控制香港人類免疫缺陷病毒 (HIV) 感染者的結核病是否有效。

設計 歷史隊列研究。

安排 香港衞生署轄下的綜合治療中心。

患者 為無結核病史的HIV感染者進行每年一次的結核菌素 敏感性測試，並為測試呈陽性反應者給予潛伏性結核 治療, 繼而跟進這些患者是否有新感染的結核病個 案。

結果 分析了接受抗逆轉錄病毒治療共 1154 例, 即5587病 人年的觀察；其中 1032 例 $(89 \%)$ 接受每年一次的 結核菌素敏感性測試。比較接受和拒絕測試的患者 的基線特徵, 發現他們的基線CD4細胞數目和結核 病的其他風險因素並沒有顯著差異。結核病總發病率 為0.59/100病人年。接受結核菌素敏感性測試的患者 的發病率 $(0.41 / 100$ 病人年) 比拒絕接受測試的為低 (3.85/100病人年) $[\mathrm{P}<0.0001 〕$ 多變量分析則 顯示, 只有低基線CD4細胞數目和曾進行結核菌素敏 感性測試為患上結核病的重要指標。在基線 CD4細胞 數目為 $100 / \mathrm{mm}^{3}$ 或以上的, 患有結核病的危險比率為 0.36（95\%置信區間：0.16-0.85；P=0.02），而曾進 行結核菌素敏感性測試的危險比率則為0.26（95\%置 信區間 : 0.08-0.77；P=0.016)。結核病的發病高峰 期是在開始抗逆轉錄病毒治療後的 90 天內。

結論 結核菌素敏感性測試和潛伏性結核治療對HIV感染者 的結核病控制仍然有效。由於研究發現開始抗逆轉錄 病毒治療後的初期有結核病高風險, 所以應盡早為病 人進行結核菌素敏感性測試。此外, 對於那些具非常 低基線CD4細胞數目的患者, 可研究在抗逆轉錄病毒 治療開始時一併使用普及的異烟胼預防治療。

then annually in all patients without a history of Mycobacterium tuberculosis infection. Positive TST reactivity was defined as an induration of $\geq 5 \mathrm{~mm}$ within 48 to 72 hours. For those with a positive result, possible active TB infection was looked into and excluded by clinical history, physical examination, chest radiography, and if necessary by sputum acid fast bacillus smear examination and culture. Those without active TB infection were treated with isoniazid preventive therapy (IPT; isoniazid $300 \mathrm{mg}$ daily) for 9 months.

In the study period (1 July 1989 to 30 June 2011), all patients under care in the ITC who were started on ART during the study period and eligible for TST were included. Tuberculosis was defined as the first recorded TB diagnosis made by physicians in the TB and chest clinics or in any other hospitals during the 
study period. Eligible patients were followed up until the development of new TB or at the end of the study period on 30 June 2011. Patients were censored at the study end-point, or when they were lost to follow-up, their care transferred to another HIV clinic, had left Hong Kong, or died. The time-to-event was counted from the date of the last negative TST result to the date of TB diagnosis. In patients who did not receive TST, the time-to-event was counted from the date of initiation of ART to the date of TB diagnosis. The TB incidence rate was defined as the number of TB cases occurring per 100 patient-years of observation. Data collected included demographic features, body mass index (BMI), route of HIV transmission, clinical and immunological markers including CD4 count and HIV-1 viral load, haemoglobin level, and history of diabetes mellitus. In addition, clinical details pertaining to their subsequent TB infection and ART regimen were retrieved from the clinical information system of the ITC. Patients with a history of TB at HIV diagnosis and those who developed TB before ART were excluded.

\section{Statistical analysis}

Logistic regression was used for univariate analysis,

TABLE I. Demographics and clinical characteristics of I I 54 patients receiving highly active ART without a history of TB*

\begin{tabular}{|c|c|c|c|}
\hline Demographics/clinical characteristic & $\begin{array}{l}\text { Received annual TST } \\
\qquad(n=1032)\end{array}$ & $\begin{array}{l}\text { Did not receive annual } \\
\text { TST }(n=122)\end{array}$ & $\mathbf{P}_{\text {value }}{ }^{\dagger}$ \\
\hline No. of patients tested TST +ve & $219(21.2 \%)$ & - & - \\
\hline No. of patients completed IPT after TST +ve & $193(88.1 \%)$ & - & - \\
\hline No. of incident TB after ART & 22 & 11 & $<0.0001$ \\
\hline Gender & & & 0.144 \\
\hline Male & $851(82.5 \%)$ & $94(77.0 \%)$ & \\
\hline Ethnicity & & & $<0.0001$ \\
\hline Chinese & $845(81.9 \%)$ & $78(63.9 \%)$ & \\
\hline Non-Chinese & $187(18.1 \%)$ & $44(36.1 \%)$ & \\
\hline HIV transmission route & & & 0.003 \\
\hline Heterosexual & $515(49.9 \%)$ & $59(48.4 \%)$ & \\
\hline MSM & $470(45.5 \%)$ & $40(32.8 \%)$ & \\
\hline IDU & $32(3.1 \%)$ & $17(13.9 \%)$ & \\
\hline Blood transfusion & $10(1.0 \%)$ & $5(4.1 \%)$ & \\
\hline Undetermined & $5(0.5 \%)$ & $1(0.8 \%)$ & \\
\hline Median body mass index $\left(\mathrm{kg} / \mathrm{m}^{2}\right)$ & 21 & 21 & 0.669 \\
\hline Age at ART (years) & & & 0.738 \\
\hline$\leq 20$ & $4(0.4 \%)$ & 0 & \\
\hline$>20$ and $\leq 30$ & $185(17.9 \%)$ & $31(25.4 \%)$ & \\
\hline$>30$ and $\leq 40$ & $400(38.8 \%)$ & $40(32.8 \%)$ & \\
\hline$>40$ and $\leq 50$ & $280(27.1 \%)$ & $26(21.3 \%)$ & \\
\hline$>50$ & $163(15.8 \%)$ & $25(20.5 \%)$ & \\
\hline Mean duration of ART (months) & 61 & 28 & $<0.0001$ \\
\hline Duration of ART before incident TB (days) & & & 0.587 \\
\hline $0-90$ & 6 & 4 & \\
\hline $91-180$ & 2 & 1 & \\
\hline$\geq 181$ & 14 & 6 & \\
\hline Median baseline CD4 count (cells/mm³) & 219 & 223 & \\
\hline Baseline HIV viral load $\left(\mathrm{cp} / \mathrm{mL}^{3}\right)$ & & & 0.01 \\
\hline$\leq 400$ & $88(8.5 \%)$ & $17(13.9 \%)$ & \\
\hline $401-10000$ & $143(13.9 \%)$ & $19(15.6 \%)$ & \\
\hline$>10000$ & $801(77.6 \%)$ & $76(62.3 \%)$ & \\
\hline Mean baseline $\mathrm{Hb}(\mathrm{g} / \mathrm{L})$ & 131.4 & 130.4 & 0.039 \\
\hline History of diabetes mellitus & $86(8.3 \%)$ & $8(6.6 \%)$ & 0.499 \\
\hline
\end{tabular}


and multivariate Cox proportional hazards regression (Forward LR) was used to calculate hazard ratios and $95 \%$ confidence intervals $(\mathrm{Cls})$ for risk factors for incident TB. CD4 count and HIV-1 viral load at baseline and at the time of TB diagnosis, as well as the duration of ART before incident TB were included as covariates. Analysis was performed using the Statistical Package for the Social Sciences (Windows version 13.0; SPSS Inc, Chicago [IL], US).

\section{Results}

\section{Study population and baseline characteristics}

From 1 July 1989 to 30 June 2011, there were 1166 patients under ITC care on ART who were eligible for TST. Twelve patients developed TB before initiation of ART and were excluded from analysis. The remaining 1154 patients included for analysis contributed to 5587 patient-years of observation. The study end-point was development of incident TB or the end of the study period. Forty-seven patients were censored for lost to follow-up in the study period, and 64 died (for reasons unrelated to TB). In all, $1032(89 \%)$ patients received annual TST and 122 patients did not. The respective median baseline CD4 counts (219 and 223 cells $/ \mathrm{mm}^{3}$ ), genders $(82.5 \%$ and $77.0 \%$ male $)$, median BMIs $\left(21 \mathrm{~kg} / \mathrm{m}^{2}\right.$ for both), and proportion with a history of diabetes mellitus $(8.3 \%$ and $6.6 \%)$ were comparable in those having and not having annual TST. Among patients who received annual TST as compared with those who did not, a larger proportion had an HIV viral load of $>10000 \mathrm{cp} / \mathrm{mL}^{3}$ (77.6\% vs $62.3 \%$; $\left.\mathrm{P}=0.01\right)$; they also had a longer mean duration of ART (61 vs 28 months, $\mathrm{P}<0.0001)$. Moreover, fewer had acquired their disease from injecting drugs $(3.1 \%$ vs $13.9 \% ; \mathrm{P}=0.003)$ or blood transfusions $(1.0 \%$ vs $4.1 \% ; \mathrm{P}=0.003)$, more were of Chinese ethnicity (81.9 vs $63.9 \% ; \mathrm{P}<0.0001$ ), and their mean haemoglobin level was also slightly higher (131.4 vs $130.4 \mathrm{~g} / \mathrm{L} ; \mathrm{P}=0.039$ ) [Table 1].

Among 1032 patients who underwent annual TST, $21.2 \%(n=219)$ tested positive, and $88.1 \%(n=193)$ of those who tested positive completed IPT (Table 1).

\section{Incidence of tuberculosis and factors associated with development of the disease}

There were 33 cases of incident TB in the cohort, making the overall incidence rate of 0.59 case per 100 patient-years, among which 21 (64\%) were pulmonary and $12(36 \%)$ were extrapulmonary. The incidence rate of TB was lower in the 22 patients who received annual TST (0.41 per 100 patient-years), as compared with that in the 11 who did not (3.85 per 100 patientyears) $[\mathrm{P}<0.0001]$. Univariate analysis showed that factors associated with development of incident TB included route of HIV transmission, baseline CD4 count, baseline haemoglobin level, and a history of TST (Table 2). Multivariate analysis showed that only a low baseline CD4 count and a history of TST were significant factors for incident TB. For those with a baseline CD4 count of $\geq 100$ cells $/ \mathrm{mm}^{3}$, the hazard ratio was $0.36(95 \% \mathrm{Cl}, 0.16-0.85 ; \mathrm{P}=0.02)$, and for those who received annual TST it was $0.26(95 \% \mathrm{Cl}, 0.08-$ $0.77 ; \mathrm{P}=0.016$ ) [Table 2].

TABLE 2. Univariate and multivariate analyses of factors associated with incident TB on HIV-infected patients receiving antiretroviral therapy

\begin{tabular}{|c|c|c|c|c|}
\hline Factor & $\begin{array}{c}\text { On ART with incident } \\
\text { TB }(n=33)\end{array}$ & $\begin{array}{c}\text { On ART without } \\
\text { incident TB }(n=1121)\end{array}$ & $P$ value, univariate ${ }^{\ddagger}$ & $\begin{array}{l}\text { P value, multivariate, },^{\S} \text { or } \\
\text { hazard ratio }(95 \% \mathrm{Cl})\end{array}$ \\
\hline Annual TST done & & & $<0.0001$ & 0.016 \\
\hline Yes & 22 & 1010 & & $0.26(0.08-0.77)$ \\
\hline No & 11 & 111 & & 1 \\
\hline Median baseline CD4 count (cells/mm³) & 95 & 222 & 0.043 & \\
\hline Baseline CD4 count (cells/mm³) & & & 0.016 & 0.02 \\
\hline$<100^{\dagger}$ & 17 & 347 & & 1 \\
\hline$\geq 100$ & 16 & 767 & & $0.36(0.16-0.85)$ \\
\hline Baseline $\mathrm{Hb}(\mathrm{g} / \mathrm{L})$ & 123 & 132 & 0.021 & - \\
\hline HIV transmission route & & & 0.031 & - \\
\hline Heterosexual & $23(69.7 \%)$ & $551(49.2 \%)$ & & \\
\hline MSM & $9(27.3 \%)$ & $501(44.7 \%)$ & & \\
\hline IDU & $1(3.0 \%)$ & $48(4.3 \%)$ & & \\
\hline Blood transfusion & 0 & $15(1.3 \%)$ & & \\
\hline Undetermined & 0 & $6(0.5 \%)$ & & \\
\hline
\end{tabular}

* ART denotes antiretroviral therapy, Cl confidence interval, Hb haemoglobin, HIV human immunodeficiency virus, IDU injecting drug use, MSM men having sex with men, TB tuberculosis, and TST tuberculin sensitivity testing

Seven patients on ART without incident TB did not have baseline CD4 count available

* By logistic regression

$\S$ By Cox regression 
TABLE 3. Incidence rates of TB in HIV-infected patients on ART with and without annual TST performed, stratified by baseline CD4 count and time since initiation of ART*

\begin{tabular}{|c|c|c|c|}
\hline \multirow{2}{*}{$\begin{array}{l}\text { Baseline CD4 count (cells } / \mathrm{mm}^{3} \text { ) with or } \\
\text { without annual TST performed }\end{array}$} & \multicolumn{3}{|c|}{ Incidence of TB per 100 patient-years } \\
\hline & $\begin{array}{l}\leq 90 \text { days of ART } \\
\text { initiation }\end{array}$ & $\begin{array}{l}\text { 91-180 Days of ART } \\
\text { initiation }\end{array}$ & $\begin{array}{l}\text { >180 Days of ART } \\
\text { initiation }\end{array}$ \\
\hline \multicolumn{4}{|l|}{$\leq 50$} \\
\hline With TST & 369 & 80 & 0.31 \\
\hline Without TST & 600 & 0 & 0 \\
\hline \multicolumn{4}{|l|}{$51-100$} \\
\hline With TST & 0 & 0 & 0.4 \\
\hline Without TST & 480 & 0 & 3.04 \\
\hline \multicolumn{4}{|l|}{$101-200$} \\
\hline With TST & 0 & 0 & 0.39 \\
\hline Without TST & 0 & 0 & 3.13 \\
\hline \multicolumn{4}{|l|}{$>200$} \\
\hline With TST & 63 & 0 & 0.18 \\
\hline Without TST & 0 & 0 & 2.19 \\
\hline
\end{tabular}

* ART denotes antiretroviral therapy, HIV human immunodeficiency virus, TB tuberculosis, and TST tuberculin sensitivity testing

\section{Tuberculosis incidence rates stratified by baseline CD4 count and timing after initiation of antiretroviral therapy}

Among patients with baseline CD4 counts of $<100$ cells $/ \mathrm{mm}^{3}$, the respective incidence rate of TB was 0.67 and 8.2 per 100 patient-years in those who received and did not receive annual TST. For patients with baseline CD4 count of $\geq 100$ cells $/ \mathrm{mm}^{3}$, the incidence rate of TB was 0.29 and 2.74 per 100 patient-years in those who received and did not receive annual TST, respectively.

The incidence of TB was highest within 90 days of initiating ART, especially for those with a low baseline CD4 count. For patients with a baseline CD4 count of $\leq 50$ cells $/ \mathrm{mm}^{3}$, the incidence rate of TB within 90 days of initiation of ART was 369 and 600 per 100 patient-years in those who received and did not receive annual TST, respectively. For patients with a baseline CD4 count of 51 to 100 cells $/ \mathrm{mm}^{3}$, none who had received annual TST developed TB within 90 days of initiation of ART, while in those who did not the incidence rate was 480 per 100 patient-years. After 180 days of ART, the incidence rate of TB in patients who underwent annual TST was below 0.5 per 100 patient-years, regardless of the baseline CD4 count. Whereas in patients who did not undergo annual TST, the TB incidence rate ranged from 2 to 3 per 100 patient-years if the baseline CD4 count was $>50$ cells $/ \mathrm{mm}^{3}$ (Table 3 ). The cumulative hazard of new TB over time after initiation of ART in patients with various baseline CD4 counts and a history of annual TST is shown in the Figure.

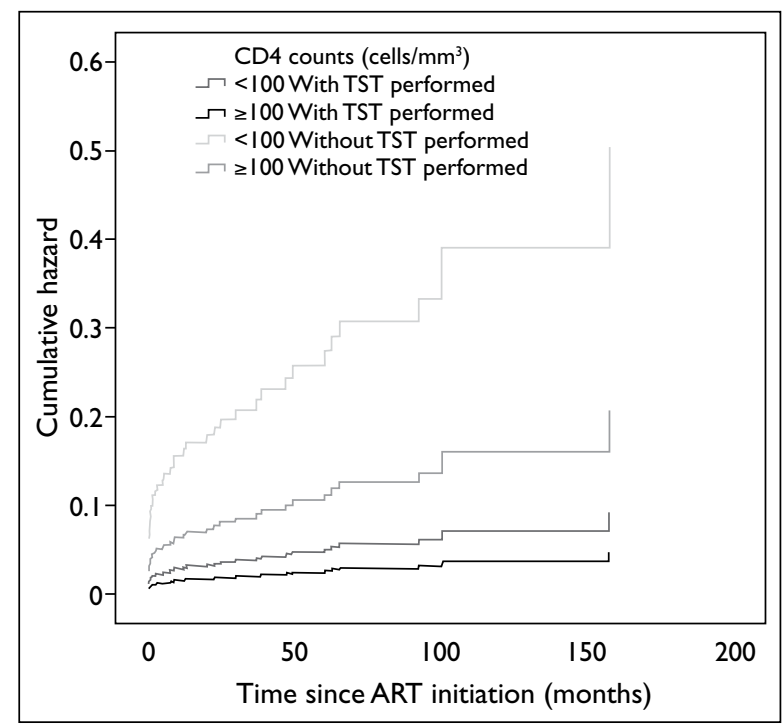

FIG. Cumulative hazard of incident tuberculosis according to baseline CD4 count and time since initiation of antiretroviral therapy

TST denotes tuberculin sensitivity testing, and ART antiretroviral therapy

\section{Discussion}

This is the first study addressing the policy of annual TST and treatment of latent TB infection in a setting of universal access to ART and an intermediate burden of TB. It showed that this policy appears to reduce the development of TB in the HIV-infected population in a setting such as Hong Kong.

In this study, the incidence of TB in HIV- 
infected patients on ART was significantly lower in those who underwent annual TST than in those who did not, despite having similar baseline CD4 counts and other risk factors for TB. Moreover, recourse to annual TST was an independent factor associated with a reduced incidence of TB; the risk being reduced by $74 \%$. Indeed, the overall incidence rate of TB in our cohort was 0.59 case per 100 patient-years, which is much lower than 0.8 to 2.83 per 100 patient-years reported in other Asian studies and in high-income settings in the ART era. ${ }^{11-15}$ This lower incidence was likely to be attributable to the high coverage of annual TST (89\%) and IPT (88\%) for those who tested positive in our centre.

Similar to the findings in other studies, ${ }^{16,17}$ we observed that the highest incidence of TB occurred in patients with advanced HIV disease during the early period of ART initiation. The incidence of TB in our patients with baseline CD4 count of $<100$ cells $/ \mathrm{mm}^{3}$ was nevertheless lower in those who received annual TST as compared with those who did not, in which the finding was also applicable within first 90 days of ART initiation. Therefore, the early use of TST, especially at baseline (before or at the initiation of ART), is warranted to identify latent TB infection in these high-risk patients. The incidence of TB occurring more than 180 days after initiation of ART was also lower in our patients who received TST as compared with those who did not. This probably reflects that the treatment of latent TB infection as identified by annual TST continues to be effective late after initiation of ART, even when the risk of TB is considered to be much lower. ${ }^{18}$ Overall, the majority of TB developed within 90 days of initiating ART. Therefore, baseline TST appears to be very important for the identification of latent TB infection followed by treatment. However, the additional value of such late repeat annual TST for all patients warrants further evaluation from the perspective of incremental benefits and costs.

Among our patients who have received TST and who had very low baseline CD4 count $(\leq 50$ cells $/ \mathrm{mm}^{3}$ ), incidence rate of TB was still high early after ART initiation, which might reflect a limitation of TST in these patients. While a recent study found that universal IPT did not reduce the incidence of TB in a population with a high TB burden, ${ }^{19}$ our findings suggest that universal IPT at ART initiation could be studied selectively in HIV-infected patients with very low baseline CD4 count.

In this study, TST was used as the gold standard for the diagnosis of latent TB infection, even though Bacillus Calmette-Guérin (BCG) vaccination is incorporated into the childhood vaccination programme in Hong Kong. However, in one study it was shown that notwithstanding prior BCG vaccination, a significant influence on TST results was not evident in HIV-infected patients. ${ }^{20}$ On the other hand, in HIV-infected patients the utility of interferon-gamma release assays (IGRAs) for the diagnosis of latent TB remains controversial, especially in settings with a high TB burden and for patients with low CD4 counts. ${ }^{21-23}$ Moreover, a recent meta-analysis did not show consistently improved sensitivity of IGRAs compared with TST for the identification of HIV-infected patients who could benefit from IPT for latent TB. ${ }^{24}$ However, in our setting with intermediate burden of TB and HIV infection, the use of IGRAs in those who did not receive TST in our cohort warrants further study. Similarly, it warrants further study in combination with TST as a means of achieving higher sensitivity and specificity for the diagnosis of latent TB infection.

We included only patients on ART in the analysis. In our centre, as of December 2011, the proportion of patients receiving combination ART was up to $85 \%$. The use of ART is well-known to reduce the risk of TB in HIV infection. ${ }^{25}$ Indeed, multivariate analysis showed that among all our patients eligible for annual TST, patients who were not on ART were strongly associated with incident TB (hazard ratio $=7.74 ; 95 \% \mathrm{Cl}$, 4.5-13.29; data not shown). Therefore, in our setting we believe that only including patients on ART reflects the genuine effectiveness of using annual TST and treatment of latent TB infection. Our study did not examine the incidence of TB in patients who were not on ART and who did not receive annual TST. However, given the high coverage of both ART and annual TST in our clinic, the proportion of such patients was small.

One limitation of our study was that though physicians who made the diagnosis of TB were blinded to HIV viral load and CD4 counts, there might have been variation in the diagnostic criteria of TB in different clinics and hospitals, especially in the small proportion of patients lacking microbiological proof. Second, in calculating the risk of incident TB, we included several known risk factors other than HIV disease status, including age, BMI, history of diabetes mellitus, and haemoglobin level. Yet data on several others (social class, ethnicity, nutritional status) were not collected, and thus not used to adjust for potential confounding. Moreover, the possibility of different exposures to TB among patients originating from places with different TB prevalences was not examined. Third, patients recruited in the later part of the study might not have been observed long enough for the development of TB. Fourth, $4 \%$ of the study population were lost to follow-up, which could have biased our analysis.

\section{Conclusion}

This study has shown the effective use of the policy of annual TST and treatment of latent TB in a setting with high coverage of ART and an intermediate TB 
burden, as prevails in Hong Kong. Further studies to consolidate the strategy, especially in those with very low CD4 counts at ART initiation, are warranted.
Alternative methods for the identification of latent TB infection in patients not having annual TST should also be studied.

\section{References}

1. Lawn SD, Churchyard G. Epidemiology of HIV-associated tuberculosis. Curr Opin HIV AIDS 2009;4:325-33. cross ref

2. World Health Organization. Global tuberculosis control. A short update to the 2009 report. Geneva: WHO; 2009.

3. Grant AD, Charalambous S, Fielding KL, et al. Effect of routine isoniazid preventive therapy on tuberculosis incidence among HIV-infected men in South Africa. JAMA 2005;293:2719-25. cross ref

4. Badri M, Wilson D, Wood R. Effect of highly active antiretroviral therapy on incidence of tuberculosis in South Africa: a cohort study. Lancet 2002;359:2059-64. cross ref

5. Girardi E, Antonucci G, Vanavore P, et al. Impact of combination antiretroviral therapy on the risk of tuberculosis among persons with HIV infection. AIDS 2000;14:198591. cross ref

6. Virtual AIDS office, Centre for Health Protection, Department of Health, Hong Kong. HIV surveillance report - 2010 update. Available from: http://www.info.gov.hk/ aids/english/surveillance/sur_archives.htm. Accessed 17 Jul 2013.

7. Centre for Health Protection, Department of Health, Hong Kong. Annual report 2009. Tuberculosis and chest service. Available from: http://www.info.gov.hk/tb_chest/doc/ AnnualReport2009.pdf. Accessed 6 Jun 2012.

8. Virtual AIDS office, Centre for Health Protection, Department of Health, Hong Kong. Available from: http://www.info.gov. hk/aids/english/index.htm. Accessed 6 Jun 2012.

9. Scientific Committee on AIDS, Centre for Health Protection, Department of Health, Hong Kong. Recommended principles of antiretroviral therapy in HIV disease. Available from: http://www.info.gov.hk/aids/english/publications/ pubsearch_2.htm. Accessed 17 Jul 2013.

10. Chan CK, Alvarez Bognar F, Wong KH, et al. The epidemiology and clinical manifestations of human immunodeficiency virus-associated tuberculosis in Hong Kong. Hong Kong Med J 2010;16:192-8.

11. Golub JE, Saraceni V, Cavalcante SC, et al. The impact of antiretroviral therapy and isoniazid preventive therapy on tuberculosis incidence in HIV-infected patients in Rio de Janeiro, Brazil. AIDS 2007;21:1441-8. cross ref

12. Zhou J, Elliott J, Li PC, et al. Risk and prognostic significance of tuberculosis in patients from The TREAT Asia HIV Observational Database. BMC Infect Dis 2009;9:46. cross ref

13. Antiretroviral Therapy in Low-Income Countries Collaboration of the International epidemiological Databases to Evaluate AIDS (leDEA); ART Cohort Collaboration, Brinkhof MW, Egger M, Boulle A, et al. Tuberculosis after initiation of antiretroviral therapy in low-income and highincome countries. Clin Infect Dis 2007;45:1518-21.

14. Rajasekaran S, Raja K, Jeyaseelan L, et al. Post-HAART tuberculosis in adults and adolescents with HIV in India: incidence, clinical and immunological profile. Indian J Tuberc 2009;56:69-76.

15. Taarnhøj GA, Engsig FN, Ravn P, et al. Incidence, risk factors and mortality of tuberculosis in Danish HIV patients 19952007. BMC Pulm Med 2011;11:26. cross ref

16. Van Rie A, Westreich D, Sanne I. Tuberculosis in patients receiving antiretroviral treatment: incidence, risk factors, and prevention strategies. J Acquir Immune Defic Syndr 2011;56:349-55. cross ref

17. Lawn SD, Myer L, Edwards D, Bekker LG, Wood R. Shortterm and long-term risk of tuberculosis associated with CD4 cell recovery during antiretroviral therapy in South Africa. AIDS 2009;23:1717-25. cross ref

18. Lawn SD, Badri M, Wood R. Tuberculosis among HIVinfected patients receiving HAART: long term incidence and risk factors in a South African cohort. AIDS 2005;19:210916. cross ref

19. Churchyard GJ, Fielding KL, Lewis JJ, et al. Community-wide isoniazid preventive therapy does not improve tuberculosis control among gold miners; the Thibela TB study, South Africa. Proceedings of the 19th Conference on Retroviruses and Opportunistic Infections; 2012 Mar 5-8; Seattle, United States.

20. Mardani M, Tabarsi P, Mohammadtaheri Z, et al. Performance of QuantiFEROM-TB Gold test compared to tuberculin skin test in detecting latent tuberculosis infection in HIV-positive individuals in Iran. Ann Thorac Med 2010;5:43-6. cross ref

21. Talati NJ, Seybold U, Humphrey B, et al. Poor concordance between interferon-gamma release assays and tuberculin skin tests in diagnosis of latent tuberculosis infection among HIV-infected individuals. BMC Infect Dis 2009;9:15. cross ref

22. Oni T, Gideon HP, Bangani N, et al. Risk factors associated with indeterminate gamma interferon responses in the assessment of latent tuberculosis infection in a high-incidence environment. Clin Vaccine Immunol 2012;19:1243-7. cross ref

23. Shanaube K, Hargreaves J, Fielding K, et al. Risk factors associated with positive QuantiFERON-TB Gold In-tube and tuberculin skin tests results in Zambia and South Africa. PLoS One 2011;6:e18206. cross ref

24. Cattamanchi A, Smith R, Steingart KR, et al. Interferongamma release assays for the diagnosis of latent tuberculosis infection in HIV-infected individuals: a systematic review and meta-analysis. J Acquir Immune Defic Syndr 2011;56:2308. cross ref

25. Jones JL, Hanson DL, Dworkin MS, et al. HIV-associated tuberculosis in the era of highly active antiretroviral therapy. The Adult/Adolescent Spectrum of HIV Disease Group. Int J Tuberc Lung Dis 2000;4:1026-31. 